\title{
İthalattaki Değişimin Genç İşsizliğe Etkisi: Türkiye Ekonomisi Üzerine Ekonometrik Bir Uygulama
}

\author{
DOI: $10.26466 /$ opus. 354850
}

\section{$\underline{\text { Hatice Cenger* - İbrahim Çütcü }}{ }^{* *}$}

\begin{abstract}
* Öğr.Gör., Muğla Sttkı Koçman Üniversitesi, Fethiye Ali Sıtkı M.K. MYO, Muğla / Türkiye E-Posta: cenger@mu.edu.tr ORCID: 0000-0002-5703-2201

* * Dr. Öğr. Ü. Hasan Kalyoncu Üniversitesi, İISBF İktisat Bölümü, Gaziantep/ Türkiye,

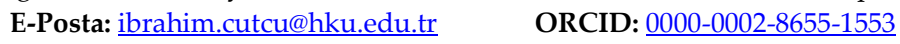

Öz

Gelişmekte olan ülkelerde en büyük sorun dışa bağıml bir ekonomik yapının varlığıdır. İthal ikameci politikalarla uzun süre çözülmeye çalışılan bu problem 1980 sonrası küreselleşme hareketleriyle birlikte önemini daha da arttırmıştır. İthalata dayalı bir piyasanın işleyişi öncelikle yurtiçi üretimi ve devamında ise istihdam politikaların negatif yönde etkilemektedir. Bu kapsamda son yıllarda sürekli dış ticaret açı̆̆ı veren Türkiye'de 2005:01 - 2017:03 dönemlerini kapsayan aylık veriler kullanılarak eşbütünleşme ve nedensellik analizleri ile ithalatın genç işsizliğe etkisi ekonometrik analizlerle yorumlanmaktadır. Yapılan analizler sonucu ADF ve PP birim kök testleri ile serilerin I(1) düzeyinde durağan olduğu Engle-Granger eşbütünleşme testine göre ise değişkenler arasında uzun dönemli bir ilişkinin olmadı̆̆ı sonucuna ulaşılmıştır. Nedensellik analizlerinde ise yapılan Granger Nedensellik ile Toda-Yamamoto nedensellik analizleri sonuçlar birbiriyle örtüşmekte olup genç işsizlik ile ithalat değişkenleri arasında uzun dönemli nedenselliğe rastlanmamıştır.

Anahtar Kelimeler: İthalat, Genç İssizlik, İstihdam

OPUS (c) Uluslararası Toplum Araştırmaları Dergisi-International Journal of Society Researches ISSN:2528-9527 E-ISSN : 2528-9535

http://opusjournal.net 


\title{
The Effects of Volume Change in Imports on Youth Unemployment: An Econometric Application on Turkish Economy
}

\begin{abstract}
The biggest problem of developing countries is their outward-bound economic structures. This problem, which has been worked out for a long time with imported substitution policies, has increased its importance with the post-1980 globalization movements. The functioning of an importbased market primarily affects domestic production and its employment policies in a negative way. In this context, in recent years, continuous foreign trade deficit in Turkey using monthly data covering the 2005:01-2017:03 periods, co-integration and causative analyses of imports with the effect of youth unemployment is interpreted with econometric analyses. As a result of the analyzes made, the results of the ADF and PP unit root tests show that series are stationary at level I (1)and there is no long-run relationship between variables according to the Engle-Granger cointegration test. In the analysis of causality, the results of Granger Causality and Toda-Yamamoto causality analyzes were overlapping and there was no long-term causality between young unemployment and import variables.
\end{abstract}

Anahtar Kelimeler: Imports, Youth Unemployment, Employment

OPUS @ C Uluslararası Toplum Araştırmaları Dergisi-International Journal of Society Researches ISSN:2528-9527 E-ISSN : 2528-9535

http://opusjournal.net 


\section{Giriş}

Genç işsizlik sorunu birçok gelişmiş ve gelişmekte olan ülkede olduğu gibi Türkiye'nin de başlıca ekonomik sorunlarından biridir. Türkiye'de genç işsizlik oranı toplam işsizliğin yaklaşık iki katı seviyesinde seyretmekte ve son yıllardaki ekonomik büyüme oranlarındaki artışa rağmen genç işsizlik oranlarında bir azalma görülmemektedir.

Gençlerin işsiz kalmaları gerek bireysel gerekse toplumsal anlamda sosyal kimliğin şekillenmesi, ekonomik bağımsızlık, sağlık sorunları, suçluluk duygusu, kendilerine saygı duymaları ve ekonomik ve politik vatandaşlıklarını düzenlemeleri konusunda önemli sorunlara yol açmaktadır(Taş ve Bilen, 2014; 53). Bu sebeple İşsizlik ve yarattığ1 sonuçlar üzerinde önemle durulması gereken önemli sosyo-ekonomik sorunlardır. Bu sebeple işsizliğin çözümlemelerinde uygulanacak olan politikaların seçimi önem arz etmektedir.

Türkiye, son yıllarda nüfus artış hızındaki düşüşe rağmen, bu oran içerisinde genç nufusu yüksek bir ülkedir. Dolayısı ile işsizlikten en çok etkilenen kesimde gençlerdir.

Gelişmiş ve gelişmekte olan bir çok ülkeyi ilgilendiren bir sorun olarak görülen genç işsizliğin sebepleri hem makro hem mikro düzeyde nedenlerden etkilenmektedir. Genç işsizliğe sebep olan faktörler hem mikro hem de makro düzeyde değerlendirilebilir. Genç işsizliğe neden olan mikro nedenler; henüz iş deneyimi kazanmamış ilk defa iş piyasasında yer edinmeye çalışan gençler, eğitimli işsizler, gençlerin nitelikleri ve çalışma eğilimleri sayılabilir. Makro düzeyde ise; ekonomik durgunluk ve belirli aralıklarla yaşanan krizler, işgücü, ücret ve eğitim politikalarının ihtiyacı karşılayacak düzeyde olmaması şeklinde özetlenebilir (Murat ve Şahin, 2011; 21). Her ne kadar gençlerin işsizlik düzeyi mikro ve makro faktörlere dayandırılsa da, genellikle işsizlik makro ekonomik göstergeler tarafından belirlenmektedir.

Genç işsizliği konusunda yapılan yazın araştırması incelendiğinde, araştırmaların genellikle genç işsizliği etkileyen unsurlar, gençlerin eğitim düzeyindeki farklılıklarının nedenleri ve genç işgücü piyasasının yapısal analizi üzerine odaklandığı görülmektedir. Bu bağlamda; İthalattaki değişimin genç işsizliğe etkisinin ekonometrik testlerle analiz 
edildiği bu çalışma ile yazın araştırmasında tespit edilen eksikliği bir ölçü de olsa giderebilmesi amaçlanmıştır.

İthalattaki değişimin genç işsizliğe etkisinin zaman serisi testleriyle analiz edildiği çalışmanın ilk bölümünde Türkiye'de diş ticaretin ve işsizliğin gelişimi aktarılırken ikinci bölümde konu ile ilgili teorik çerçeve ve literatür özetine yer verilmiştir. Ekonometrik yöntem ve ekonometrik analiz sonuçlarının yer aldığı üçüncü bölümün ardından ise sonuç ve politika önermeleri ile çalışma tamamlanmaktadır. Belirtilen metodolojik sıramada öncelikle konulara ilişkin kavramsal çerçeve oluşturulmakta ve teorik altyapı karşılanmaktadır. Kavramsal çerçevenin ardından "dış ticaret ile işsizlik arasında ilişki vardır" hipotezi literatür üzerinden ulusal ve uluslararası çalışmalar ile irdelenmektedir. Çalışmanın analiz boyutunda ise TUIK'ten elde edilen ithalat ve genç işsizlik verileri aylık bazda eşbütünleşme ve nedensellik analizleri ile test edilmektedir. Analizlerden önce serilerin birim kök içerip içermediğinin anlaşılması için $\mathrm{ADF}$ ve PP birim kök testleri yapılmıştır. Değişkenler arasında eşbütünleşme ilişkisinin analizi için Engle-Granger Eş-bütünleşme analizi ve değişkenler arasındaki nedensellik ilişkisinin tespiti için ise Granger Nedensellik Analizi ile birlikte yeni nesil ekonometrik testlerden kabul edilen Toda-Yamamoto Nedensellik analizi kullanılmış. Ekonometrik analizlerin tümü E-Views 9 ve Gauss 10 programları kullanılarak gerçekleştirilmiştir.

\section{Teorik ve Kavramsal Çerçeve}

Türkiye'nin dış ticaretine genel olarak bakıldığında, ticaret fazlası verdiği yıllar istisna sayılacak kadar azdır. İstihdam politikalarının başarılı olabilmesi için dış ticaret dengesinin fazla vermesi gerekir. Bir ülkenin kalkınmasında esas ve önemli unsurlardan biri olan dış ticaret, küresel rekabet de stratejik bir rol oynamaktadır. Ülkenin karşılaştırmalı üstünlüğe sahip ürünlerinde ihracat yapılarak kazanılan dövizle, gerekli yatırımların gerçekleştirilmesi ve dış borçların ödenmesine olanak sağlanırken cari dengede pozitif gelişmeler yaratılabilmektedir.

Bir sektörün kullandığı girdileri oluşturan ara malları, yerli üreticiden değil de yurtdışından alınırsa, belli koşullar altında, büyümede bir azalma olmadan ülke içinde istihdamın düşmesi, dolayısıyla işsizliğin 
artması beklenir. Bu sebeple istihdam yaratmayan büyüme kavramını incelerken sektörlerarası işlemlerin göz önünde bulundurulması gerekecektir. İthalata dayalı büyüme olarak da ifade edilebilen bu süreç sürdürülebilir olmayıp uzun dönemde yerli üretimi, GSYH'yı ve devamında işsizlik verilerini olumsuz yönde etkilemektedir. Etkin korumacilık politikaları olarak ifade edilebilen ithalat yasakları, kotalar ve gümrük tarifeleri ile bu süreç zamanla tersine çevrilebilmekte ve ayrıca kamusal teşvik ve sübvansiyonlar doğru bir şekilde yaygınlaştırılabilmektedir.

\section{Türkiye'de İthalatın Yapısı ve Üretim-İşsizlik Etkisi}

Dış ticaretin gelişmesiyle birlikte ülkeler birbirlerine daha çok bağlanmakta ve öncelikli olan yatırım malların ithal edebilmek için ihracattan kaynaklanan gelirlerini arttırmak zorunda kalmaktadırlar. $\mathrm{Bu}$ nedenle dış ticaret kazanım ve kayıpları önem arz etmekte diğer bir ifadeyle dış ticaret haddindeki değişmeler gittikçe büyük önem kazanmaktadır(Keskin, 2009: 19).

Türkiye'nin dış ticaretine genel olarak bakıldığında, ticaret fazlası verdiği yıllar istisna sayılacak kadar azdır. Türkiye Cumhuriyeti 1923 yılından 1980 yılına kadar ithal ikameci bir sanayileşme stratejisini izlemiştir. Bu sayede yeni kurulan sanayi dalları gümrük vergileri ve diğer korumaca önlemlerle korunmuş, iç piyasaya üretim yaparak bir anlamda tekel konumunda gelişmeleri sağlanmıştır.

Dış ticaretin serbestleştirilmesine ilişkin düzenlemeler ihracata ve ithalata yönelik olarak ihracat ve ithalat önündeki sınırlamaların kaldırılmasını amaçlayarak yapılmıştır. Bu düzenlemelerle amaçlananlar; milli gelirin ve dolayısı ile ekonomik büyümenin artırılması için yurt içinde ihracata yönelik üretimi artırmak, büyüme ve üretim için gerekli olan yarı mamul, hammadde ve yatırım malları ithalatını kolaylaştırarak ilgili kalemlerin teminatını sağlamak seklinde sayılabilir. Fakat bu çabalar beklendiği sonuçlanmamış ve günümüzde ihracatımız ithalatımıza bağlı duruma gelmiştir(Kösekahyaoğlu ve Şentürk, 2006:42).

Türkiye'de dışa açılma sürecinin hız kazandığı1980'li yıllarda, daha önce ithalatı yasak olan çoğu ürünün ülkeye girmesi üzerindeki yasağın kaldırılmasıyla birlikte ortaya çıkan ithalat artışı, dış ticaret açı̆̆ı so- 
rununu beraberinde getirmiştir. Bu bağlamda dişa açılma ile birlikte ülkemizde ihraç ürün çeşitliliği artmış ve Türkiye yeni pazarlara açılarak ihracat hacmini de arttırmıştır. İthalat ve ihracat açısından ortaya çıkan bu her iki olumlu gelişmeye rağmen ne yazık ki ülkemizde söz konusu dönem sonrasında genel olarak mal ve hizmet ithalatı, mal ve hizmet ihracatından daha fazla görülmüş ve bunun sonucu olarak, dış ticaret açığ1 ülke ekonomisi için yapısal bir sorun haline gelmiştir(Çelik ve İlkay, 2016: 962). Özellikle bu dengesizliğin sebebi, Türkiye'de sanayinin üretim yapısının büyük ölçüde ithal ara ve yatırım mallarına bağımlı olmasının yarattığı ithalat artışından kaynaklanmaktadır(Çiftçi ve Çapkın, 2013:179).

Türkiye 2001 krizi ve sonrasında uygulanan "Güçlü Ekonomiye Geçiş Programı" başlığı altında Uluslararası Para Fonunun (IMF) desteği ile makro düzeyde yeni düzenlemelere gidilmiştir. Bu yapısal reform ağırlıklı program, enflasyonun ortadan kaldırılması, kamu maliyesinin sağlıklı bir yapıya kavuşturulması şeklinde oluşturulmuş ekonomide temel bir dönüşüme yol açmış ve ekonomide göreli istikrarın sağlanmasına katkıda bulunmuştur (Kol ve Karaçor, 2001:381).

Programda dişa acık politikalarla istihdamın arttırılması hedeflenmektedir. Ancak yapılan çalışmalarda, Türkiye'deki makro ve mikro gelişmeler bir bütün olarak değerlendirildiğinde, bu ticaret hacminin katma değer ve istihdam üzerindeki yansımalarının kısıtlı olduğu görülmektedir (Yükseler ve Türkan, 2008: 163).

Çalışmanın analiz kısmında da test edilecek olan ithalatın genç işsizliğe etkisi gelişmekte olan ülkelerde önemli bir sorun olarak görülmektedir. Gelişmekte olan ülkeler sıcak para çekebilmesi için finansal küreselleşmenin arttığı günümüz dünyasında yüksek faiz düşük kur politikasına yönelmektedir. Fakat uygulanan bu politikalar ithal girdilerin maliyetini düşürdüğü için yurtiçi üretimi olumsuz yönde etkilemektedir. Yerli sanayinin dışa bağımlılığının artması ve üretimin düşmesi şeklinde sonuçlanan bu süreç muhakkak ki işsizliği de etkilemektedir. Üretimden çok tüketimin ön plana çıkarılması ile de tasarruf yetersizliği ortaya çıkmakta ve tasarruf eksikliği ise son yıllarda en önemli makro ekonomik sorun olan cari açığı tetiklemektedir(Çiftçi ve Çapkın, 2013:162). 


\section{İstihdam, İşsizlik ve Genç İşsizlik Kavramlarının Teorik Çerçevesi}

İstihdam kavramının tanımı incelendiğinde hem dar hem de geniş anlamda kullanıldığ1 görülmektedir. Geniş anlamda istihdam kavramı; bütün üretim faktörlerinin mal ve hizmet üretmek amaciyla üretim sürecinde kullanılmasını kapsarken, dar anlamda istihdam kavramı ise sadece emek faktörünün mal ve hizmet üretmek amaciyla üretim sürecinde kullanılmasını kapsamaktadır. Bu nedenle bir ekonomide emek faktörünün eksik istihdamı varsa o ekonomide işsizlik sorunu bulunmaktadır (Uysal, 2007: 55).

TÜİK işsizi, "Referans dönemi içerisinde istihdam halinde olmayan (kâr karşılı̆̆ı, yevmiyeli, ücretli ya da ücretsiz olarak hiç bir işte çalışmamış ve böyle bir işle bağlantısı da olmayan) kişilerden iş aramak için son üç ay içinde iş arama kanallarından en az birini kullanmış ve onbeş gün içinde işbaşı yapabilecek durumda olan, kurumsal olmayan çalışma çağındaki tüm kişiler" şeklinde tanımlamaktadır(TÜİK, 2011).

İşsizliğin uluslararası standart tanımı ise, işi olmamama, işe başlamaya hazır olma ve iş arıyor olma şeklinde üç kritere dayanmaktadır. Bu kriterler DİE tarafından da onaylanmış olup bu üç üç kriterin aynı anda varlığı işsiz sayılmayı gerekli kılmaktadır (Köstekli, 1999: 8).

ILO(uluslararası Çalışma Örgütü)'nün tanımına göre genç işsizler ise; 15-24 yaşları arasında bulunan, referans döneminde bir saatten fazla çalışmamış olan, ve aktif olarak iş arayan kişi olarak tanımlanabilir. (Çetinkaya, 2010: 46). 15-24 yaş grubunun maruz kaldığ1 işsizlik türü olarak tanımlayabildiğimiz genç işsizlik, gençlerin işsizlikten daha çok etkilenmesi sebebiyle ayrıca ele alınmaktadır. Toplumun diğer kesimlerine göre işsizlikten daha çok etkilenen dezavantajlı gruplar arasında özürlüler, kadınlar, niteliksiz işçiler, yabancı işçiler de bulunabilir. Ancak en önemli paya sahip olan gençlerdir (Gündoğan, 1999, s. 64).

Türkiye genelinde 2012 yılında \%8,4 ile dip yapan işsizlik oranı o tarihten sonra yükselişe geçmiştir. 2015 yılında bu oran $\% 10,3$ olarak gerçekleşmiştir. 2015 yılında iş gücüne katılma oranı 2014 yılına göre $\% 0,8$ puan artarak \%51,3 düzeyine yükselmiştir. Bu oran 2005 yılından bu yana yıllık bazda gerçekleşen en yüksek işgücüne katılma oranı olarak görülmüştür. 2017-2019 Orta Vadeli Program tahminlerine göre; işgücüne katılma oranının 2016 yılı için \%51,8 2019 yılında \%53,5, işsizlik 
oranının 2016 yılı için \%10,5 2019 yılı sonunda ise \%9,8 olması öngörülmektedir.(İSKKUR, 2017: 16).

Bilginin giderek üretim faktörleri içerisinde yerini alması sebebiyle gelişmiş ülkeler istihdamda bilgi toplumunun ihtiyaçlarına yönelik iş gücü yetiştirme çabası içine girerken, Türkiye gibi gelişmekte olan ülkeler bu değişim sürecinin genel sorunları yanında bilgi toplumunun ihtiyaçlarından doğan yeni sorunlarla da uğraşmak zorunda kalmaktadırlar. Bu nokta deneyimsiz ve gerekli niteliklere haiz olmayan dezavantajlı grupların istihdama katılamaması, bunlar içinde de işsizlik oranları önemli seviyede seyreden "gençlerin" istihdamı önemli bir sorun olarak ortaya çıkmaktadır (Ata, 2007:112).

Genç işsizliğin nedenleri iki temel noktada analiz edilebilir. İlki genç işsizlikteki dalgalanmaların temel belirleyicilerinin nedenleri ve ekonomik koşullardaki değişme karşısında genç işsizliğin yetişkin işsizlik karşısındaki artış oranının nedenleri, ikincisi ise, gençlerin hangi özelliklerinin işsiz kalma ya da istihdama katılma şansını artırıp azalttığ 1 konusudur. İlki iş gücü piyasasına makro bir düzeyde yaklaşmayı gerekli kılarken, ikincisi mikro düzeyde gençlerin özelliklerinin araştırılmasını kapsamaktadır(Gündoğan, 2001: 18-19).

Makro düzeydeki işsizlik politikalarının başarısı, istikrarlı ve nispeten yüksek bir ekonomik büyümenin sağlanmasını gerekli kılar. Ekonomik istikrar sağlandığı taktirde, istikrarlı yüksek büyüme hızı gözlemlenirken, ihracata yönelik sanayileşmede mümkün olacaktır. İşsizlikle mücadelede mikro düzeyde politikaların başarısı ise, Türkiye'de işsizliğin güçlü-avantajlı ve zayıf-dezavantajlı yönlerinin iyi analiz edilmesine bağlıdır (Gürsel ve Ulusoy, 1999: 136-137).

\section{Ekonometrik Analiz}

Ekonometrik analiz bölümünde çalışmada ağırlıklı işlenen genç işsizliğin nedenleri olarak görülen ithalatın genç işsizliğe etkisi ve iki değişken arasındaki ilişki test edilmektedir. Bu kapsamda öncelikle veri seti ve kurulacak ekonometrik model tanitilacak devaminda izlenecek metodoloji aktarılacak ve sonunda ise elde edilen bulgular yorumlanacaktır. 


\section{Veri Seti ve Ekonometrik Model}

Çalışmada ithalat ile genç işsizlik arasındaki ilişki TUIK'den elde edilen veriler ile test edilmektedir. Analizlerde 2005:01 - 2017:03 dönemlerini kapsayan aylı veriler ile eşbütünleşme ve nedensellik analizleri yapılarak iki değişken arasındaki ilişkiler araştırılmakta ve politika önermeleri sunulmaktadır.

Analizde kullanılan temel modelin ana kalıbı şu şekildedir;

$$
\mathrm{YU}_{\mathrm{t}}=\beta_{0}+\beta_{1} \mathrm{LM}_{\mathrm{t}}+\varepsilon_{\mathrm{t}}
$$

Modelde kullanılan $\mathrm{YU}_{\mathrm{t}}$ genç işsizlik değişkenini ifade etmekte olup bağımlı değişken olarak, $\mathrm{LM}_{\mathrm{t}}$ ise ithalatı temsil etmekte olup bağımsız değişken olarak modele dahil edilmiştir.

\section{Metodoloji}

İthalat ile genç işsizlik arasındaki ilişkinin analiz edildiği çalışmada izlenen metodoloji şu şekilde ifade edilebilir. Hipotezin test edilmesi için ekonometrik çalışmada kullanılan analizler eş bütünleşme ve nedensellik testleridir. Testlerden önce kullanılacak değişkenlere ait serilerin durağanlığ1 ADF ve PP testleri ile ölçülmüştür. Serilerin aynı düzeyde durağan olması durumunda iki değişken arasında ki eş bütünleşme ilişkisinin tespiti için Engle-Granger Eş-bütünleşme analizi ve modele dahil edilen değişkenlerin karşılıklı nedensellik ilişkilerinin ortaya çıkarılabilmesi için Granger Nedensellik analizi ile birlikte yeni nesil ekonometrik testlerden kabul edilen Toda-Yamamoto Nedensellik analizi kullanılmış ve hipotezler karşılaştırmalı olarak yorumlanmıştır. Çalışmada tüm analizler EViews 9 ve Gauss 10 paket programları kullanılarak gerçekleştirilmiştir.

\section{Birim Kök Test Sonuçlar}

Sosyal bilimlerde hipotez testlerinde kullanılan ekonometrik analizlerden önce serilerin birim kök içerip içermediğini incelemek 
gerekmektedir. Çünkü birim kök içeren seriler literatürde durağan olmayan seriler olarak ifade edilmekte olup sahte regresyon sorunu ile karşılaşma riskini barındırmaktadır. Analizlerde birim köklü seriler durağan değildir ve durağan olmaya serilere sahip olan değişkenler arasındaki eşbütünleşme ilişkisine bakılamaz ve bakılsa dahi çıkan ilişkilerin anlamlı olduğu söylenemez (Harris ve Sollis, 2003: 41). Seriler birim köklü ise sahte regresyon sorunu vardır denilir, R2 ve $t$ değerleri anlamlı olsa dahi yapılacak iktisadi yorumlar anlamsız olacaktır (Sevüktekin ve Çınar, 2014:324). Bu nedenlerden dolayı ithalat ve genç işsizlik değişkenleri 2005:01 - 2017:03 dönemlerini kapsayan aylık veriler ile serilerin durağanlığı, Augmented Dickey-Fuller (1979) ile PhillipsPerron'un (1988) geliştirdiği yöntemlerle analiz edilmiştir.

Tablo 1: ADF ve PP Birim Kök Testi Sonuçları

\begin{tabular}{|c|c|c|c|c|c|c|c|c|c|}
\hline \multirow{9}{*}{$\begin{array}{l}\vec{N} \\
: \mathcal{D}\end{array}$} & & Değişkenler & ADF & $\mathrm{PP}$ & & & Değişkenler & $\mathrm{ADF}$ & $\mathrm{PP}$ \\
\hline & & \multirow[t]{2}{*}{ YU } & $1,95(4)$ & $1,66(5)$ & & \multirow{4}{*}{ 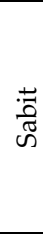 } & \multirow[t]{2}{*}{ YU } & $-4,94(3)$ & $\begin{array}{c}-10,23 \\
(4)\end{array}$ \\
\hline & 菲 & & {$[0.3061]$} & {$[0.4491]$} & & & & {$[0.0001]^{*}$} & {$[0.0000]^{*}$} \\
\hline & $\bar{n}$ & \multirow{2}{*}{ LM } & $-2,61(12)$ & $-3,39(0)$ & $\frac{\vec{t}}{\vec{z}}$ & & \multirow[t]{2}{*}{ LM } & $\begin{array}{c}-15,94 \\
(0)\end{array}$ & $\begin{array}{c}-16,54 \\
(0)\end{array}$ \\
\hline & & & {$[0.0916]^{* * *}$} & {$[0.0125]^{* *}$} & $\frac{\pi}{\sigma}$ & & & {$[0.0000]^{*}$} & {$[0.0000]^{*}$} \\
\hline & $\bar{E}$ & \multirow[t]{2}{*}{ YU } & $-2,01(4)$ & $-1,73(4)$ & . & \multirow{4}{*}{ 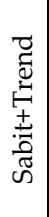 } & \multirow[t]{2}{*}{ YU } & $-4,97(3)$ & $\begin{array}{c}-10,22 \\
(4)\end{array}$ \\
\hline & \multirow{3}{*}{ 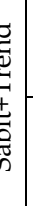 } & & [0.5882] & {$[0.7307]$} & & & & {$[0.0004]^{*}$} & {$[0.0000]^{*}$} \\
\hline & & \multirow[t]{2}{*}{ LM } & $-2,90(12)$ & $-3,72(3)$ & & & \multirow[t]{2}{*}{ LM } & $\begin{array}{c}-15,96 \\
(0)\end{array}$ & $\begin{array}{c}-16,64 \\
(5)\end{array}$ \\
\hline & & & {$[0.01637]^{* *}$} & {$[0.0235]^{* *}$} & & & & {$[0.0000]^{*}$} & {$[0.0000]^{*}$} \\
\hline
\end{tabular}

Not: ${ }^{*},{ }^{* *}$ ve ${ }^{* * *}$ karakterleri $\% 1, \% 5$ ve \%10 seviyesinde serilerin durağanliğın ifade etmektedir. Parentez içinde gösterilen rakamlar, ADF testi için Schwarz, PP için kernel yöntemine göre optimal gecikme uzunluğunu gösterir. Gecikme uzunluğunun sıfır olması durumunda ise DF testini gösterir. Analizin olasıllı değgerini ise köşeli parantez içindeki değerler göstermektedir.

Durağanlık analizi sonuçları incelendiğinde; ADF ve PP test sonuçlarına göre sabitli modelde $Y U$ değişkeninin durağan olmadığ $\mathrm{LM}$ değişkeninin ise $\mathrm{ADF}^{\prime}$ de $\% 10 \mathrm{PP}^{\prime}$ da ise $\% 5$ düzeyinde durağan olduğu fakat her iki değişkenin de birinci dereceden farkları alındığında $\% 1$ anlamlılık düzeyinde durağan olduğu görülmektedir. Sabitli ve trendli modelde ise YU değişkeninin birim köklü olduğu LM değişkeninin ise ADF ve PP testlerinde \%5 düzeyinde durağan çıktığ fakat her iki değişkenin de birinci dereceden farkları alındığında \%1 an- 
lamlılık düzeyinde durağanlaştığı sonucuna ulaşılabilir. Durağanlık testleri sonuçları özetlendiğinde ise LM ve YU değişkenlerinin birinci dereceden farkları hesaplanığında I(1) seviyesinde durağan hale geldiği söylenebilir.

\section{Engle-Granger Eş-Bütünleşme Testi}

Durağanlık testlerinin ardından, ekonometrik çalışmalarda iki veya daha fazla değişkenin uzun dönemde birlikte hareket edip etmedikleri eş-bütünleşme testleri ile analiz edilmektedir. Değişkenler arasındaki uzun dönemli ilişki, serilerin farkları alındıktan sonra aynı seviyede durağan hale getirilmesinin ardından Johansen-Juselius (1992) ve EngleGranger (1987) testleri kullanılarak analiz edilmektedir (Barışık ve Demircioğlu, 2006: 76). Çalışmada uygulamadaki genelliği ve basitliği açısından en sık tercih edilen Engle-Granger Eş Bütünleşme testi kullanılmıştır. Engle- Granger eşbütünleşme testi, kalıntıların analizine dayalı bir testtir. Engle- Granger testinde öncelikle birinci dereceden durağan olan iki değişken ile bir regresyon modeli kurulmaktadır (Yilanc1, 2009: 208):

$$
\mathrm{Yt}=\alpha 0+\alpha 1 \mathrm{x} 1+\mathrm{ut}
$$

Analizin ikinci aşamasında ise En Küçük Kareler Yöntemi ile hata terimi tahmin edilir ve bu regresyondan elde edilen kalıntılarla bir otoregresif model kurularak kalıntıların durağanlığına bakılır.

$$
\Delta \mathrm{ut}=\Delta \mathrm{Q} \text { ut }-1+\text { et }
$$

Burada $\varrho=0$ ise, kalıntılar serisi birim köklüdür ve iki değişken arasında eş-bütünleşme ilişkisi yoktur şeklinde yorumlanır. Çalışmada 2005:01 - 2017:03 dönemlerini kapsayan aylık veriler ile ithalat (LM) ile genç işsizlik (YU) arasındaki ilişki analiz edilmektedir. Birim kök testleri sonucunda seriler I(1) düzeyinde durağan olmasından dolayı EngleGranger testinin yapılabileceği sonucuna ulaşılmıştır. Engle-Granger Eş Bütünleşme test sonuçları Tablo 2'de görülmektedir. 
Tablo 2: Engle-Granger Eş-Bütünleşme Testi (LX - LGE)

\begin{tabular}{cccc}
\hline $\begin{array}{c}\text { ADF Test } \\
\text { İstatistiği }\end{array}$ & \multicolumn{4}{c}{ Engle-Granger Eşbütünleşme Testi Kritik Değerleri } \\
\hline \multirow{2}{*}{$\mathbf{2 . 1 3}$} & $1 \%$ & $5 \%$ & $10 \%$ \\
\cline { 2 - 4 } & 4,00 & 3,37 & 3,02 \\
\hline
\end{tabular}

İthalat ile genç işsizlik arasındaki eş bütünleşme analizinden çıkartılan kalıntılar serisinin ADF durağanlık testi sonucu elde edilen test istatistiği, Engle-Granger' in simülasyonlarla elde ettiği kritik değerleri ile karşılaştırıldığında, -2.13 değerinin mutlak değeri \%1 - \%5 - \%10 kritik değerlerinden küçük olduğu görülmektedir. Bu nedenle ithalat ile genç işsizlik arasında uzun dönemli bir ilişkinin varlığından söz edilemez.

\section{Granger Nedensellik Testi}

Ekonometrik nedensellik analizlerinde, belirlenen zaman serisi verilerinin ilerleyen yıllardaki değerlerinin, kendisine ait veya başka bir değişkenin yıllık verilerinin geçmiş değerlerinden etkilenerek elde edilmesidir (Isığıçok, 1994: 94). Granger Nedensellik testinde kurulan regresyon modelindeki bağımsız değişkenin gecikmeli değerlerinin anlamlılıklarına bakılır. Burdan çıkacak sonuca göre iki değişken (X - Y) arasında X, Y'nin Granger nedenidir şeklinde yorumlanır ve $\mathrm{X} \rightarrow \mathrm{Y}$ şeklinde gösterilir (Granger,1969: 424-438). Bu analizlerden elde edilen sonuçlar ile geleceğe dönük tahminlerde bulunulamaz fakat değişkenler arasındaki nedensellik ilişkileri yorumlanabilir.

Tablo 3: Granger-Nedensellik Testi

\begin{tabular}{lll}
\hline Nedensellik İlişkisi & F İstatistiği & Sonuç \\
\hline $\mathbf{L M} \rightarrow$ YU & $1.9174(0.1733)$ & Red \\
\hline $\mathbf{Y U} \rightarrow$ LM & $3.5872(0.6102)$ & Red
\end{tabular}

* Parentez içindeki değer Prob. olasillk değerini göstermektedir. ${ }^{* *}$ Uygun gecikme uzunluğu $H Q$ ve SC bilgi kriterine göre 5 alımııstır.***äzlem sayısı 147'dir.

Granger nedensellik testleri sonuçlarından anlaşılacağı gibi, ithalat ile genç işsizlik değişkenleri arasında herhangi bir nedensellik ilişkisi görülmemiştir. Bu sonuçlardan iki değişken arasında uzun dönemli bir 
eşbütünleşme ilişkisinin olmadığı gibi ayrıca herhangi bir nedensellik ilişkisinin de olmadığı sonucuna ulaşılmaktadır.

\section{Toda Yamamoto Nedensellik Analizi}

İthalat ile genç işsizlik arasındaki nedensellik ilişkisinin analizi Granger Nedensellik testinin dişında yeni nesil ekonometrik analizlerde sıkça kullanılan Toda-Yamamoto (1995) analiziyle tekrar test edilmiştir. Bunun nedeni ise son zamanlarda Granger Nedensellik testlerinde değişkenlerin eşbütünleşik olması şartının analizi bağımlı hale getirmesidir. Toda-Yamamoto testine göre, VAR analizleriyle gerçekleştirilen nedensellik araştırmalarında değişkenler arasındaki görülebilecek eşbütünleşme ilişkisi önemli değildir. Burada önemli olan kurulacak modelin doğru belirlenmesi ve maksimum bütünleşme derecesinin hesaplanması yeterlidir (Kızılgöl ve Baykal, 2008: 356). Bu analizde değişkenlerin düzey değerlerinin olduğu VAR modelinin tahmin edilebilmesi ve Wald testinin uygulanabilmesi için serilerin durağan olmasına gerek yoktur. Toda ve Yamamoto analizinin kullanıldığ 1 yöntemde, Granger nedensellik analizi için [k+(dmax)] mertebesinden VAR modeli tahmin edilir ve katsayıların olduğu matrise Wald testi uygulanır. Analizde, modelde kullanılan değişkenlerin durağan, trend de durağan ve eşbütünleşme ilişkisinin olup olmadığına bakılmaksızın, testin $\mathrm{k}$ serbestlik derecesi ile asimptotik $2 \chi$ dağılımına sahip olduğunu ispatlamaktadır. Analizde kullanılan $\mathrm{k}$ maksimum bütünleşme derecesini gösterir. Dolayısıyla analizin ilk adımında modelde yer alan değişkenlerin bütünleşme derecesi hesaplanır daha sonar ise sistem tahmini gerçekleştirilir (Yavuz, 2006: 169). İthalat ile genç işsizlik serileri arasındaki nedensellik ilişkisinin Toda-Yamamoto analizi ile incelenmesinden önce bütünleşme derecelerinin hesaplanması gerekmektedir. LM ve YU değişkenleri için yapılan $A D F$ ve PP birim kök testlerinde tüm değişkenlerin I(1) seviyesinde durağan olduğu görülmüştür. Bu nedenle dmax=1 alınır.

Tablo 4: UzunluğuVAR Modeli Bilgi Kriterlerine Göre LM-LYU Uygun Gecikme Uzunluğu

\begin{tabular}{ccccccc}
\hline Lag & $\operatorname{LogL}$ & LR & FPE & AIC & SC & HQ \\
\hline 0 & -293.3348 & NA & 0.240188 & 4.249421 & 4.291644 & 4.266579
\end{tabular}




\begin{tabular}{lllllll}
1 & -5.673070 & 562.9063 & 0.004055 & 0.167958 & 0.294626 & 0.219432 \\
2 & 4.248890 & 19.13011 & 0.003724 & 0.082750 & 0.293863 & 0.168541 \\
3 & 11.22145 & 13.24286 & 0.003569 & 0.039979 & 0.335538 & 0.160086 \\
4 & 20.10190 & 16.61090 & 0.003327 & -0.030243 & 0.349761 & 0.124180 \\
5 & 27.11121 & $12.90923^{*}$ & $0.003187^{*}$ & $-0.073543^{*}$ & $0.390907^{*}$ & $0.115197^{*}$ \\
6 & 29.58254 & 4.480404 & 0.003259 & -0.051547 & 0.497347 & 0.171509 \\
7 & 31.97060 & 4.260709 & 0.003338 & -0.028354 & 0.604986 & 0.229018 \\
8 & 34.69928 & 4.789911 & 0.003402 & -0.010062 & 0.707723 & 0.281627 \\
\hline
\end{tabular}

Serbestlik derecesi (k) için ise AIC-SC-HQ bilgi kriterlerine göre Tablo 4 'te görüldüğü üzere gecikme sayısının 5 olduğu görülmektedir. Bu nedenle $\mathrm{k}+\mathrm{dmax}=(5+1)=6$. dereceden VAR modelinde nedensellik analizi gerçekleştirilmiştir.

Tablo 5: Toda - Yamamoto Nedensellik Analizi Sonuçları

\begin{tabular}{ccccc}
\hline $\begin{array}{c}\text { Temel } \\
\text { Hipotezler }\end{array}$ & $\begin{array}{c}\text { Gecikme } \\
\text { Uzunluğu } \\
(\mathrm{k}=5, \mathrm{dmax}=1)\end{array}$ & F-İstatistiği & P-eğeri & Sonuç \\
\hline $\begin{array}{c}\text { İthalat genç } \\
\text { işsizliğin } \\
\text { nedenidir. }\end{array}$ & 6 & 4,5804 & 0.5986 & $\begin{array}{c}\text { İthalat genç işsizliğin } \\
\text { Toda ve Yamamoto } \\
\text { analizine göre nedeni } \\
\text { değildir. }\end{array}$ \\
\hline $\begin{array}{c}\text { Genç } \\
\text { işsizlik } \\
\text { ithalatin } \\
\text { nedenidir. }\end{array}$ & 6 & 6,7443 & 0.3451 & $\begin{array}{c}\text { Genç işsizlik ithalatın } \\
\text { Toda ve Yamamoto } \\
\text { analizine göre nedeni } \\
\text { değildir. }\end{array}$ \\
\hline
\end{tabular}

Tablo 6'da ki Toda-Yamamoto analizi sonuçları incelendiğinde her iki modelde de bütünleşme derecesinin 6 olduğu ve anlamlılık değerlerine bakıldığında ise 0,10 'dan büyük olduğu için kurulan hipotezlerin red edildiği sonucuna ulaşılır. Elde edilen bu sonuca göre de Granger Nedensellik analizi ile Toda-Yamamoto analizi sonuçları birbiriyle örtüşmektedir ve yapılan çalışmada gerçekleştirilen iki nedensellik analizinden de aynı sonuca ulaşılabilmektedir. Nedensellik analizleri özetlendiğinde ise ithalat ile genç işsizlik arasında çift yönlü herhangi bir nedensellik ilişkisine rastlanmamıştır.

\section{Sonuç ve Değerlendirme}


İşsizlik, dışa bağımlı üretim yapısı ve yıllardır kronikleşmiş olan dış ticaret açığı ile gelişmekte olan ülke kategorisinde yer alan Türkiye için çözülmesi gereken önemli bir makro ekonomik sorundur. Ekonomik büyümenin arttığı ülkelerde işsizliğin azalması gerektiğini belirten teorik yaklaşımlara rağmen Türkiye ekonomisi son 10 yıldır sürekli büyüyen yapısına rağmen işsizlik rakamlarını istenilen seviyeye çekememiştir. Bunun sebebi olarak birçok etken sayılabilirken en önemli gerekçe olarak üretim bazlı büyümenin sağlanamaması söylenebilir.

Makroekonomik istikrar söylemlerinde genel olarak enflasyon, büyüme, bütçe gibi değişkenlerden bahsedilirken aslında işsizlik kavramı da ülkenin önemli bir sosyo-ekonomik değişkenidir. İşsizlik sorunu diğer birçok değişkeni de etkilediği gibi ülke de ki asayiş, terör gibi sıkıntıları da tetiklemektedir. Türkiye gibi genç nüfusa sahip ülkelerde ise bu sorun genç işsizlik olarak ayrı bir kategoride incelenmekte ve ona göre önlem paketleri hazırlanmaktadır. Genç işsizlik tüm dünyada olduğu gibi Türkiye'de de özellikle 2008 küresel krizinden sonra artış yönlü bir ivme yakalamıştır. Neredeyse her dört gençten birisinin işsiz olduğu Türkiye'de bu soruna dönük önemli teşvikler ve projeler hayata geçirilmektedir.

Çalışmada genç işsizlik sorununa ithalat harcamaları üzerinden yaklaşılmaktadır. İthalat harcamaları, özellikle dış ticaret açığı ve cari açık sorunlarına neden olmasından dolayı ülke ekonomileri için en kırılgan değişkenlerden biridir. Türkiye ekonomisi için düşünüldüğünde, yıllardır başta hammadde ve yarı mamul ürünler ile birçok tüketim mallarının ithalatı dolayısıyla ödemeler dengesinde önemli açıklar yaşamıştır. Bu açıkların kapatılması ve ihracatın gelişmesi için önemli kamusal destekler sunulmuş ve birçok sektörde büyük teşvik paketleri açıklanmıştır. Fakat geliştirilen tüm önlemlere rağmen dış ticaret açığı ve cari açık sorunu uzun dönemde çözülememiştir. İthalat değişkeninin, çalışmanın konusu olan genç işsizliğe etkisi ise yerli üretimin kısılması şeklinde ortaya çıkmaktadır. İthal ürünlerle rekabet edemeyen yerli üretici bu durumda üretimi durdurmak zorunda kalmakta bu ise işsizliği ve özellikle de eğitimli, kalifiye olan genç işsizliği olumsuz yönde etkilemektedir.

Son yıllarda kronikleşmiş hale gelen diş ticaret açığının temel nedeni olan ithalat verileri ile genç işsizlik arasındaki ilişkinin incelendiği 
çalışmada 2005:01 - 2017:03 dönemlerini kapsayan aylık veriler kullanılmıştır. İki değişken arasındaki eşbütünleşme ve nedensellik analizlerinden önce serilerin durağanlık testleri gerçekleştirilmiş olup yapılan ADF ve PP birim kök testleri sonucunda serilerin farkları alındıktan sonra I(1) düzeyinde durağan hale geldiği görülmüştür. Çalışmanın analiz kısmında eşbütünleşme testi olarak Engle-Granger testi kullanılmış olup elde edilen sonuçlara göre değişkenler arasında uzun dönemli bir ilişkiye ulaşılamamıştır. Nedensellik analizlerinde ise literatürde en çok kullanılan Granger nedensellik analizi ile yeni nesil testlerden olan Toda-Yamamoto nedensellik analizleri kullanılmıştır. Gerçekleştirilen her iki nedensellik analizinde de ithalat ile genç işsizlik arasında uzun dönemli bir nedensellik ilişkisine rastlanmamıştır.

Eşbütünleşme ve nedensellik analizlerinde görüldüğü üzere Türkiye ekonomisinde referans dönemlerde ithalattaki değişim ile genç işsizlik arasında bir ilişki görülmemektedir. Elde edilen amprik sonuçlara göre genç işsizlik sorununun çözümü için dış ticaret politikalarından ziyade yapısal değişimlere ve politikalara ihtiyaç vardır. Bu kapsamda yapılması gereken öncelikle gençlerin çalışma alanlarının genişletilerek istihdam alanları yaratılmasıdır. Bunun içinde kapsamlı bir genç işsiz profili çıkartılarak birçok sektörü de içinde barındıran istihdam stratejisi oluşturulmalıdır. Bu sürece ise devlet ile birlikte işçi ve işveren örgütleri de dahil edilmesi gerekmektedir.

Yeni istihdam alanları gençlerin iş hayatına girmesini etkilerken çalışma koşullarının iyileştirilmesi ve geliştirilmesi de gençlerin iş hayatına girmesini belirleyecektir. Çünkü gerek çalışma saatleri gerekse çalışma koşulları ve ücretleri gençlerin maalesef küresel dünyada beklentilerini karşılayamamaktadır. Bu sorunun çözümü için uluslararası standartların yakalanması hususunda tüm tarafların düzenleme yapması gerekmektedir. Ayrıca genç nüfusunda kendisini piyasanın ve sektörün ihtiyaç duyduğu niteliklere göre donanımlı hale getirmesi çok önemlidir. Çünkü Türkiye'de birçok sektörde alanında uzman, kalifiye eleman eksikliği görülmektedir. Bu nedenle gençlerin de kendi gelişimlerine önem vermeleri ve inovatif düşünceleri hayata geçirmeleri gerekir.

\section{Kaynakça}


Ata, N. (2007).Türkiye'de işgücü piyasasının yapısı ve genç işsizlik. TísK Akademi, 2(ö.s.1), 109-118.

Barışık, S. ve Demircioğlu, E. (2006). Türkiye'de döviz kuru rejimi, konvertibilite, ihracat-ithalat ilişkisi (1980-2001). ZKÜ Sosyal Bilimler Dergisi, 2(3), 71-84.

Çelik, T. ve İlkay, S., Ç. (2016). Türkiye'de ihracat ve ithalat arasındaki ilişkinin 1989-2015 dönemi için test edilmesi. Süleyman Demirel Üniversitesi İktisadi ve İdari Bilimler Fakültesi Dergis, 21(3), 961-969.

Çetinkaya, E. (2010). Genç işsizliğin teorik açıklamaları. Sosyal Siyaset Konferanslarl Dergisi, 58, 45-57.

Çiftçi, N. ve Çapkın, R.,(2013). Türkiye ekonomisinde cari açık ve işsizlik arasındaki ilişkinin var tekniğ ile analizi. İnönü Üniversitesi Uluslararası Sosyal Bilimler Dergisi, 2(2), 157-182.

Dickey, D. A. ve Fuller,W. A. (1981). Likelihood ratio statistics for auto regressive time series with a unitroot. Econometrica, 49(4), 10571072.

Engle, R.F. ve Granger, C. W. J. (1987). Co-integration and error correction: Representation, estimation, and testing. Econometrica, 55(2), 251-276.

Granger, C. W. J. (1969). Investigating causal relations by econometric models and cross-spectral methods. Econometrica, 37(1), 424-438.

Gündoğan, N., (1999). Genç işsizliği ve Avrupa Birliği'ne üye ülkelerde uygulanan genç istihdam politikaları. Ankara Üniversitesi Siyasal Bilgiler Fakültesi Dergisi, 54(1), 63-79.

Gündoğan, N., (2001). Genç işsizliği. Eskişehir: T.C.Anadolu Üniversitesi Yayınları No: 1320, İİ.B.F. Yayınları No: 173.

Gürsel, S. ve Ulusoy V., (1999), Türkiye'de işsizlik ve istihdam. İstanbul Yapı Kredi Yayınları, Cogito/Ekonomi-87, 1. Bask1, Ağustos, İstanbul.

Harris, R. And Sollis, R. (2003). Applied time series modelling and forecasting. England: John Wiley\&Sons Ltd.

Işığıçok, E. (1994). Zaman serilerinde nedensellik çözümlemesi. Bursa: Uludağ Üniversitesi Basımevi. 
İşkur, Türkiye işgücü piyasası analizi, Türkiye Geneli İPA Raporu, http://www.iskur.gov.tr/kurumsalbilgi/raporlar.aspx\#dltop BU (Erişim 03.07.2017)

Johansen, S. ve K. Juselius. (1992). Testing structural hypotheses in a multivariate cointegration analysis of the ppp and uip for U.K. Journal of Econometrics, 53, 211-244.

Kaynak, M.,(2007). İşsizlik ve emek kalitesi. TISK Akademi, 2(Özel Sayı:1), 67-86.

Keskin, Ş., (2009). Döviz kuru politikaları-dış ticaret hadleri ilişkisi Türkiye uygulaması (1987-2007). Yayınlanmamış Yüksek Lisans Tezi, Kütahya Dumlupınar Üniversitesi Sosyal Bilimler Enstitüsü.

Kızılgöl, Ö. ve Erbaykal, E. (2008). Türkiye'de turizm gelirleri ile ekonomik büyüme ilişkisi: Bir nedensellik analizi. Süleyman Demirel Üniversitesi İktisadi Ve İdari Bilimler Fakültesi Dergisi, 13(2), 351-360.

Kol, E., Nida. ve Karakoç Z. (2001). Güçlü ekonomiye geçiş programı ve istihdam üzerine etkileri. Maliye Dergisi, 162, 379-395.

Kosekahyaoğlu L., ve Sentürk C., (2006). İhracata Dayalı Büyüme Hipotezinin Testi: Türkiye ve yeni gelişen ekonomiler üzerine karşılaştırmalı bir inceleme. S.D. ̈̈. Sosyal Bilimler Enstitüsü Dergisi, 2(4),23-45.

Köstekli, Ş. İ.,(1999). Dünyada ve Türkiye'de işsizlik. Ankara: Türk-İş Eğitim Yayınları No: 24.

Murat, S. ve Şahin, L. (2011).Nedenleri ve sonuçları bakımından gençler arasında yaygınlaşan işsizlik. Sosyoloji Konferansları Dergisi, 44, 148

Phillips, P.C.B. ve Perron, P. (1988). Testing for a unit root in time series regression. Biometrika, 75(2), 335-346.

Sayın, F. (2011). Türkiye'de 1988-2010 döneminde eğitim ve büyümenin genç işsizliğine etkisinin analizi. Dokuz Eylül Üniversitesi Sosyal Bilimler Enstitüsü Dergisi, 13(4), 33-53.

Sevüktekin, M. ve Çınar, M. (2014). Ekonometrik zaman serileri analizi, Bursa: Dora Yayınları.

Taş H. Y. ve Bilen, M. (2014). Avrupa Birliği ve Türkiye'de genç işsizliği sorunu ve çözüm önerileri. Hak-Iş̧ Uluslararası Emek ve Toplum Dergisi, 3(6), 50-69. 
Toda, H.Y. ve Yamamoto, T.(1995). Statistical inference in vector autoregressions with possibly integrated process. Journal Of Econometrics, 66, 225-250.

Tüik, (2011). <www.tuik.gov.tr>Türkiye istatistik kurumu işgücü maliyeti endeksi: III. Dönem 2011, İnternet Adresi: http://www.tuik.gov.tr/ PreHaberBultenleri.do?id=8660 Erişim Tarihi: 06.07.2017

Uysal, D. (2007). "Türkiye istihdam, işsizlik ve istihdam politikaları", Türkiye ekonomisi makroekonomik sorunlar ve çözüm önerileri içinde (Editör: Ahmet AY), Konya: Çizgi Kitabevi.

Yılanc, V. (2009). Fisher hipotezinin Türkiye için sınanması: Doğrusal olmayan eşbütünleşme analizi. Atatürk Üniversitesi İktisadi Ve İdari Bilimler Dergisi, 23(4), 205-213.

Yılmaz, A., ve Karataş, T. (2009). Türkiye ekonomisinde 2001 krizi sonrası süreçte cari işlemler açığının nedenleri üzerine bir inceleme. Marmara Üniversitesi İ.̇.B.F. Dergisi, 27(2), 69-96.

Yukseler, Z. Ve E. Turkan, (2008). Türkiye'nin üretim ve dış ticaret yapısında donüşüm: Küresel makroekonomik yönelimler ve yansimalar. TUSİAD Yayınları, No:TUSİAD-T/2008-02/453.

\section{Kaynakça Bilgisi / Citation Information}

Cenger, H. ve Çütcü, İ (2018). İthalattaki değişimin genç işsizliğe etkisi: Türkiye ekonomisi üzerine ekonometrik bir uygulama. OPUS Uluslararası Toplum Araştırmaları Dergisi, 8(Gençlik Araştırmaları Özel Sayısl), 485-503. 